\title{
Rett Syndrome: From the Gene to the Disease
}

\author{
Tanja Matijevic Jelena Knezevic Marko Slavica Jasminka Pavelic \\ Rudjer Boskovic Institute, Division of Molecular Medicine, Zagreb, Croatia
}

\section{Key Words}

MECP2 gene $\cdot$ Neurodevelopmental disorder $\cdot$ Rett

syndrome

\begin{abstract}
Rett syndrome (RTT, MIM No. 312750) is a progressive neurodevelopmental disorder and one of the most common causes of mental retardation. It is transmitted as an X-linked dominant trait, therefore almost exclusively affecting females. About $80 \%$ of RTT cases are sporadic caused by mutations in the MECP2 gene located on Xq28. The gene codes for two isoforms of the methyl-CpG-binding protein (MeCP2, MeCP2B) which are involved in transcriptional silencing through DNA methylation. The gene has 4 exons. The fourth one is the largest. Almost all mutations in MECP2 occur de novo. Although mutations are dispersed throughout the gene, about $67 \%$ of all MECP2 mutations, caused by C>T transitions at $8 \mathrm{CpG}$ dinucleotides, are located in the third and fourth exon. The most common mutation is R168X. So far, there is no clear evidence on genotype-phenotype correlations. There are also reports claiming that the same mutation can provoke different phenotypes. It was shown that $\mathrm{MeCP} 2$ can silence certain genes. One of them, brain-derived neurotrophic factor, is essential for neural plasticity, learning and memory. This discovery revealed the role of $\mathrm{MeCP} 2$ in the control of neuronal activity-dependent gene regulation and suggested that the pathology of RTT may result from deregulation of this process.
\end{abstract}

Copyright $\odot 2008$ S. Karger AG, Base (c) 2008 S. Karger AG, Basel

0014-3022/09/0611-0003\$26.00/0

Fax +4161306 1234 E-Mail karger@karger.ch www.karger.com
Accessible online at:

www.karger.com/ene

\section{Introduction}

Rett syndrome (RTT, No. MIM 312750) is a progressive neurodevelopmental disorder and one of the most common causes of mental retardation in females. Its name comes from Andreas Rett who first described it in 1966 [1] but the syndrome was internationally recognized after Hagberg et al. [2] described 35 cases in 1983. RTT is characterized by apparently normal development for the first 6-18 months of life, followed by a period of regression in language and motor skills. The patients lose purposeful hand use and replace them with repetitive stereotyped hand movements. They usually have normal head circumference at birth followed by postnatal deceleration of head growth. Social withdrawal, communication dysfunction, loss of acquired speech and cognitive impairment are also characteristic of RTT patients. The impairment of locomotion is also very common. Additional characteristics include autistic features, panic-like attacks, respiratory dysfunctions (episodic apnea and/or hyperpnea), bruxism, impairment of sleeping patterns, progressive kyphosis or scoliosis, decreased somatic growth and hypotrophic small and cold feet and/or hands $[3,4]$. After initial regression, the condition stabilizes. Patients may recover some skills and usually survive into adulthood, but the incidence of sudden, unexplained death is significantly higher than in controls of a similar age. It may be due to longer corrected QT intervals and T wave abnormalities [5]. Mutations in the MECP2 gene which encodes the methyl-CpG-binding protein (MeCP2) cause approximately $80 \%$ of RTT cases [6]. MeCP2 is in-

Prof. Dr. Jasminka Pavelic

Rudjer Boskovic Institute, Division of Molecular Medicine, Laboratory of Molecular Oncology, Bijenicka 54

HR-10002 Zagreb (Croatia)

Tel. +385 14560 926, Fax +385 1456 1010, E-Mail jpavelic@irb.hr 
volved in transcriptional silencing through DNA methylation. It is expressed in all tissues; therefore, this was an unexpected finding because RTT was thought to be primarily a neurodevelopmental disorder.

MECP2 maps to the $\mathrm{X}$ chromosome; so mutations in this gene are usually lethal in males and they can rarely survive. The occurrence of mutations in the MECP2 gene in living males is usually connected with different types of mosaicism or mild forms of mutations.

\section{Structure and Function of the MECP2 Gene and Protein}

MECP2 maps between L1CAM and the RCP/GCP loci in Xq28 and undergoes X chromosome inactivation (XCI) $[7,8]$. The gene has 4 exons. MeCP2 is an abundant, ubiquitously expressed nuclear protein of 486 amino acids most frequently encoded by a second, third and fourth exon. However, in 2004, Mnatzakanian et al. [9] identified the previously unknown isoform of MeCP2 called MeCP2B; it employs exons 1, 3 and 4, skipping exon 2. They identified a deletion of $11 \mathrm{bp}$ in exon 1 in 1 affected girl after screening 19 girls with typical RTT without mutations in exons 2,3 or 4.

The fourth exon of the MECP2 gene is the largest one; it contains a long $(>8.5 \mathrm{~kb}) 3^{\prime}$-untranslated region, with several polyadenylation sites that enable the generation of multiple transcripts of different lengths. Alternative polyadenylation in the $3^{\prime}$-untranslated region results in a highly expressed $10.1-\mathrm{kb}$ transcript in the fetal brain and a $5-\mathrm{kb}$ transcript in the adult brain [10].

The MeCP2 protein contains four functional domains: (1) a methyl-CpG-binding domain (MBD, 85 amino acids) which binds to 5-methyl cytosine with a high affinity; (2) a transcriptional repression domain (TRD, 104 amino acids) which interacts with histone deacetylase and transcriptional corepressor SIN 3A; (3) the nuclear localization signal which may be responsible for the transport of MeCP2 into the nucleus, and (4) the C-terminal segment which facilitates its binding to the nucleosome core. Interactions between this transcription repressor complex and chromatin-bound $\mathrm{MeCP} 2$ lead to deacetylation of core histones $\mathrm{H} 3$ and $\mathrm{H} 4$ by histone deacetylases resulting in compaction of the chromatin, making it inaccessible to components of the transcriptional machinery. In addition, $\mathrm{MeCP} 2$ can perform histone deacetylase-independent transcriptional repression [11]. DNA-methylation-dependent repression is important for XCI and genomic imprinting.
$\mathrm{MeCP} 2$ is expressed in all tissues and it was first hypothesized to act as a global transcriptional repressor [7, 12]. Interestingly, recent studies show that MeCP2 does not act as a general repressor. Colantuoni et al. [13] found that in postmortem brain tissues of RTT patients the expression of multiple neuron-specific mRNA was decreased. Tudor et al. [14] investigated the difference in global gene expression between mutant (MeCP2-null) and wild-type mice. They hypothesized that mutant mice should have transcriptional deregulation throughout the genome. However, the results showed only subtle gene expression changes in the brains of mutant mice. In addition, it was thought that in the brain MECP2 is expressed only in neurons and not in nonneuronal cells. However, MECP2 is also expressed in nonneuronal cells, presumably astrocytes, and not only in the nucleus but also in the cytosol [15]. These findings are important because nonfunctional MECP2 may cause a decrease in the neuronal body size and dendritic trees; this may be connected with microcephaly and specific behavior in RTT. Furthermore, it has been suggested that MeCP2 plays a central role in neuronal maturation. The study of postnatal brain development in an Mecp2-deficient mouse model showed that Mecp2 was not critical for the production of immature neurons but for neuronal maturation. In addition, analysis of gene expression profiles showed abnormal expression levels of a number of genes important for synaptogenesis [16].

Interestingly, Nikitina et al. [17] reported that hMecp2 binds to the linker DNA region of nucleosomes and protects it from micrococcal nuclease action. Thus, Mecp2 mutants show a different level of protection depending on the type of the mutation.

Nan et al. [18] have recently shown that Mecp2 interacts with the ATRX protein which is a SWI2/SNF2 DNA helicase/ATPase mutated in the ATRX syndrome (alphathalassemia/mental retardation, X-linked). In addition, ATRX localization is disrupted in neurons of Mecp2-null mice. They also showed that point mutations within the DNA binding domain of MECP2 that would normally cause RTT inhibit interactions with ATRX in vitro and its localization in vivo.

\section{RTT-Causing Mutations}

Almost all mutations in MECP2 occur de novo. The exceptions are familial cases where the mutation has been inherited from a healthy or mildly affected mother; they either have a gonadal mosaicism or favorable XCI. About 
$67 \%$ of all MECP2 mutations are caused by $\mathrm{C}>\mathrm{T}$ transitions at 8 CpG dinucleotides (R106, R133, T158, R168, R255, R270, R294 and R306) which are located in the third and fourth exon. The most common mutation is R168X. Although mutations are dispersed throughout the gene, a clustering of missense mutations occurs $5^{\prime}$ of the TRD, mostly in the MBD; they all involve evolutionarily conserved amino acids in functional domains of the protein. Nonsense, frameshift and splicing mutations appear distal to the MBD and result in premature termination of the protein. Larger multinucleotide deletions occur in the C-terminal domain. Although deletions tend to affect the same region, entirely identical deletions are rare. It is hypothesized that truncated proteins still bind methylated DNA but cannot interact with the corepressor SIN 3A [19].

Three studies on RTT patients of Slavic origin, including ours [20-22], have been published so far. In all studies, one of the most common mutations, T158M, R168X, $\mathrm{R} 270 \mathrm{X}$ and $\mathrm{R} 133 \mathrm{C}$, has been found as well as rather common C-terminal deletions. These data do not differ to a great extent from the data collected in other studies conducted on patients of different origins [23-28].

Since in some RTT patients no MECP2 mutations could be found, it was proposed that there is at least one other locus responsible for RTT. Indeed, two groups of authors described cases of RTT-like phenotypes caused by truncating frameshift and missense mutations in the gene for cyclin-dependent kinase-like 5 (CDKL5; OMIM No. 300203), which is also known as serine/threonine protein kinase 9 (STK9) and is mapped to the Xp22 region $[29,30]$. It was suggested that CDKL5 and MECP2 play a role in a common pathogenic process [31]. Mutations that cause the disease can be found in the catalytic domain and in the $\mathrm{COOH}$ region. Bertani et al. [32] showed that the wildtype CDKL5 autophosphorylates and is responsible for $M E C P 2$ phosphorylation. On the other hand, the mutated protein shows impaired and increased catalytic activity.

Borg et al. [33] reported a girl with characteristics of the RTT bearing translocation-involved chromosomes 1 and 7. On chromosome 1, the Netrin G1 gene was disrupted while on chromosome 7 all genes were intact. Since Netrin G1 is mostly expressed in the brain and is important in the central nervous system development it was suggested that Netrin G1 is a potential novel gene candidate for the RTT. On the other hand, Archer et al. [34] tested Netrin G1 for mutations on 115 patients with the RTT but found only few sequence variants and none of them appeared to be pathogenic. Therefore, they concluded that mutations in Netrin G1 very rarely cause RTT.

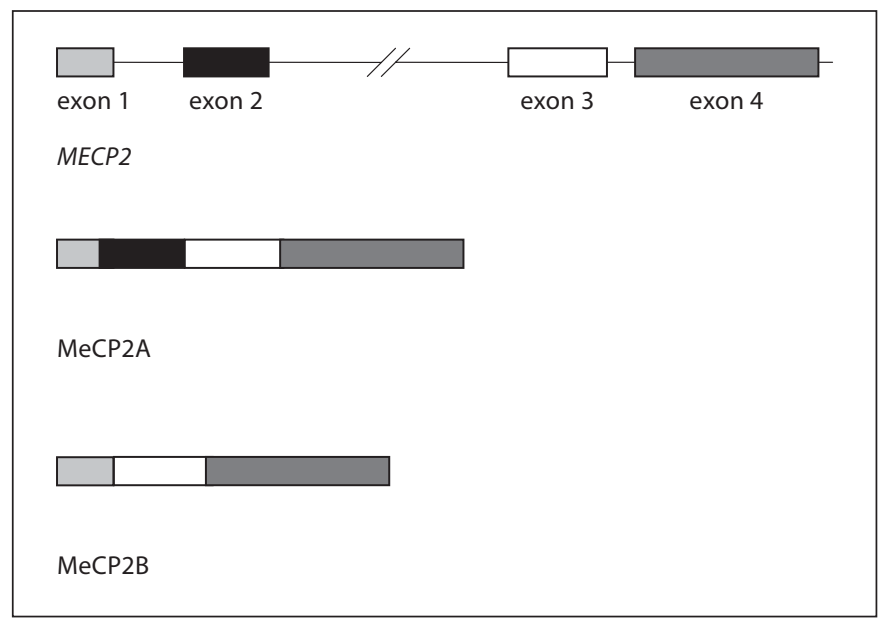

Fig. 1. The structure of MECP2. The MECP2 gene consists of 4 exons and there are 2 splice variants: $\mathrm{MeCP} 2 \mathrm{~A}$ which includes all 4 exons and $\mathrm{MeCP} 2 \mathrm{~B}$ which skips exon 2 and includes only exon 1 , exon 3 and exon 4.

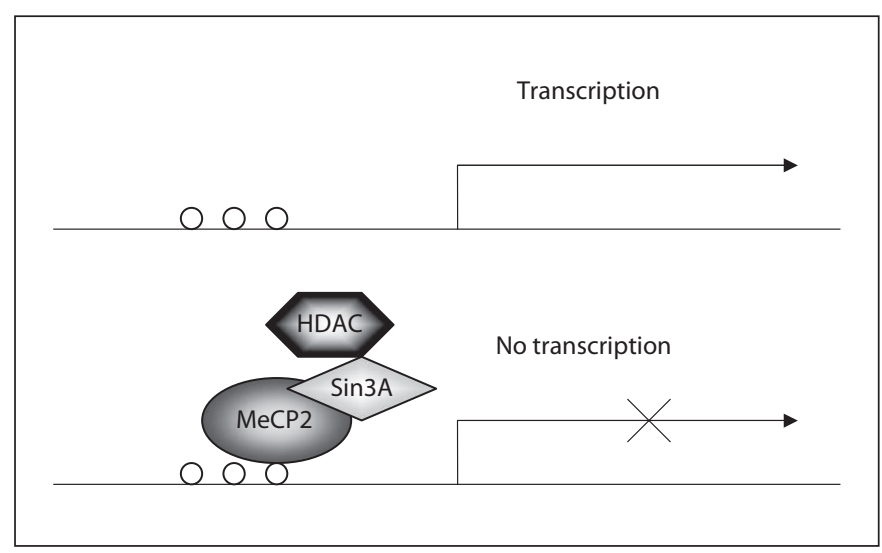

Fig. 2. MeCP2 function. MeCP2 acts as a transcription repressor. It binds to methylated $\mathrm{CpG}$ and through the Sin $3 \mathrm{~A}$ corepressor recruits histone deacetylases (HDAC), which leads to deacetylation of the core histones $\mathrm{H} 3$ and $\mathrm{H} 4$. The result is compacted chromatin which the transcription machinery cannot access.

\section{Genotype-Phenotype Correlations}

Genotype-phenotype correlation studies have so far yielded conflicting results. Some researchers have not found a genotype-phenotype correlation between the type of mutation and clinical features but some of them have found such a correlation [34-37]. Later on, a milder form of the disease was found in patients carrying missense mutations as compared to those with truncating mutations; milder disease was also associated with late 
but not with early truncating mutations $[38,39]$. However, large deletions can also be found in very mildly and in severely affected patients [39]. Huppke et al. [40] showed that patients who carry either missense mutation or deletion located within the hotspot region for deletions, an area between 1,030 and 1,207 bp of the MECP2 gene, have a milder phenotype than other patients. They also found that all mutations that lead to either a complete or partial truncation of the region coding for the nuclear localization signal are associated with a severer phenotype than other truncating mutations. They did not find a significant difference between the patients with mutations in the MBD and those with mutations in the TRD but concluded that the mutation type and location are connected with the phenotype in the RTT.

There are also reports claiming that the same mutation can provoke different phenotypes [32, 41]. This suggests that not only the type of mutation influences phenotype severity; XCI might be an additional factor.

Recently, Scala et al. [42] have reported a case of one identical intragenic MECP2 deletion, probably due to gonadal mosaicism, found in two sisters with a contradictory phenotype: one classic and one 'highly functioning' preserved speech variant. In a later case, epigenetic or genetic causes other than $M E C P 2$ were most certainly modulators of phenotype severity.

\section{Effect of XCI}

The inactivation of one of the $\mathrm{X}$ chromosomes occurs randomly in differentiating embryonal cells in females, resulting in cells that are mosaic with respect to which chromosome is active. The purpose is to equalize X-linked gene products between XX females and XY males.

The MECP2 gene undergoes $\mathrm{X}$ inactivation. In one study, it was shown that of 34 patients with classic RTT $91 \%$ had random XCI [36]. Nonrandom XCI was associated with milder phenotypes; preferential inactivation of the $\mathrm{X}$ chromosome with mutated MECP2 gene protects against the deleterious effects of mutations. Females, carriers of RTT-causing mutations but asymptomatic or who suffer from only mild learning disability, had a nonrandom XCI [43].

Most studies of XCI done so far involved determination of the XCI pattern using lymphocytes of peripheral blood or established lymphoblastoid cell lines. However, it turned out that blood cells are not the right model for researching epigenetic and genetic mechanisms of RTT pathogenesis; there is no evidence that the exact XCI pat- tern is found in the brain tissues. On the contrary, there is at least one case that demonstrates that there is no connection between XCI of leukocytes and XCI of the brain. It was observed that a girl with the classic RTT, where the mutation was on the paternal X chromosome, had an inactive paternal X chromosome in peripheral leukocytes. It is known that in highly differentiated brain cells, especially neurons, different genes are expressed than in peripheral blood lymphocytes. Archer et al. [44] have recently reported that there is a correlation between clinical severity in patients with the RTT (p.R168X or p.T158M MECP2 mutation) and a proportion of the active mutated allele. They pointed out that XCI may vary in neurological and hematological tissues, and showed a relationship between the degree and direction of XCI in leukocytes and clinical severity in the RTT.

\section{RTT Mutations in Males}

The frequency of potentially disease-causing MECP2 mutations in the population of mentally retarded male patients is between 1.3 and $1.7 \%$ [45]. Males with mutations in the MECP2 gene usually suffer from severe neonatal encephalopathy and die within 1-2 years of birth. However, males with a mild MECP2 mutation that would most likely produce a very mild phenotype in girls (late truncating mutations and some missense mutations) can survive but they develop severe mental retardation associated with motor abnormalities. There are also few examples of males who developed an RTT phenotype; they either have somatic mosaicism for the mutation [46] or a partial or complete Klinefelter (47,XXY) karyotype [47]. Maiwald et al. [48] reported a 46,XX male with RTT caused by a mutation in the MECP2 gene; the clinical manifestation of the boy resembled female RTT cases, which was explained by the karyotype. Also, the rather mild phenotype was due to the preferential expression of the normal allele.

Interestingly, there are mutations that are only found in males with the RTT phenotype. For example, the A140V mutation has never been reported in a girl with a classical RTT phenotype but it was found in 4 severely retarded males from the same family [49].

\section{MeCP2 Target Genes}

It was shown that $\mathrm{MeCP} 2$ can silence certain genes (table 1). LINE1 but not Alu retrotransposons are repressed by $\mathrm{MeCP} 2$ in transfection assays [50]. The leukosialin gene 
Fig. 3. Overlapping and nonoverlapping between RTT and MECP2.70-80\% of classic RTT patients have mutations in the $M E C P 2$ gene but RTT can also be caused by mutations in the CDKL5 and Netrin G1 gene. On the other hand, mutations in $M E C P 2$ have been connected with several other diseases (e.g. X-linked MR, autistic spectrum disorders) as well as with carriers who have no apparent phenotype.

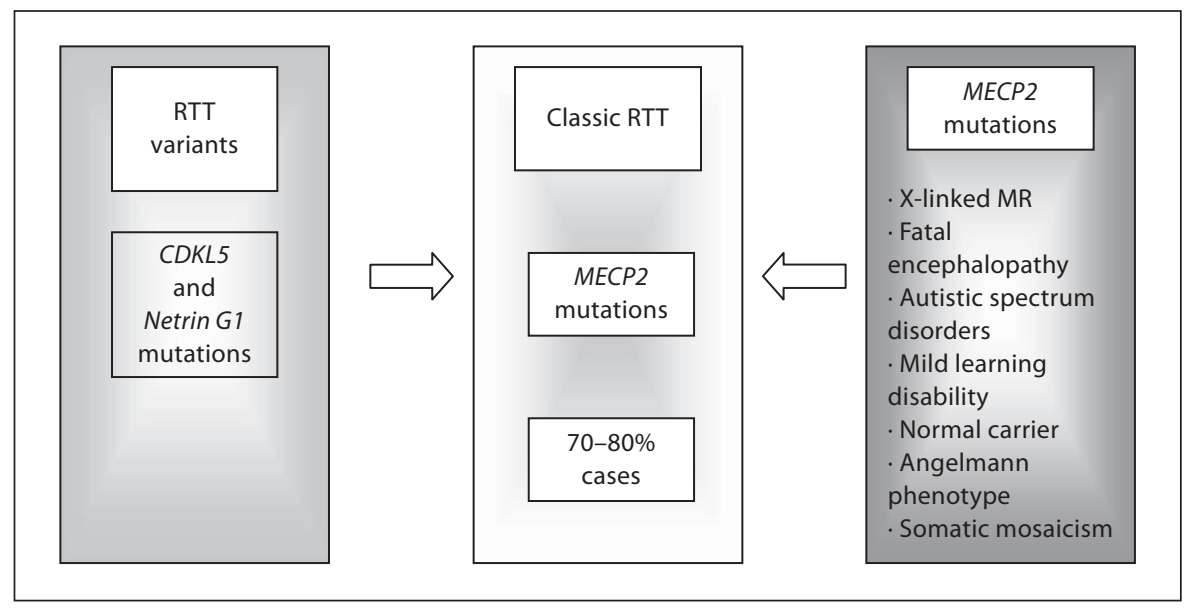

is also repressed by $\mathrm{MeCP} 2$ when the promoter is methylated but it was not confirmed that MeCP2 binds to this promoter in vivo [51]. However, the $\mathrm{MeCP} 2$ target genes associated with RTT pathogenesis could not be found.

Two groups of authors have discovered that $\mathrm{MeCP} 2$ regulates the expression of the gene encoding brain-derived neurotrophic factor (BDNF) [52, 53]. BDNF is essential for neural plasticity, learning and memory. MeCP2 binds selectively to BDNF promoter III and represses the expression of the BDNF gene. Membrane depolarization causes the influx of calcium ions and consequent phosphorylation of $\mathrm{MeCP} 2$, which is released from BDNF promoter III; this facilitates activation of BDNF transcription. This discovery revealed the role of MeCP2 in the control of neuronal activity-dependent gene regulation and suggested that the pathology of RTT may result from deregulation of this process. In 2006, Chang et al. [54] discovered that the overexpression of $B d n f$ with a conditional $B d n f$ transgene in mice extends the life span, rescues a locomotor defect, and reverses an electrophysiological deficit observed in Mecp2 mutants. Their results showed that a functional interaction between Mecp2 and Bdnf exists in vivo.

Another possible MeCP2 target gene is the so-called distal-less homeobox 5 (DLX5; OMIM No. 600028) [55]. This gene was thought to be an imprinted gene and to regulate the production of enzymes that synthesize $\gamma$ aminobutyric acid (GABA). Namely, the transcription of DLX5 was roughly two times greater in brains of Mecp2null mice than in wild-type mice. An imprinted gene is the one with a methylated promoter and is usually silent. If the $\mathrm{MeCP} 2$ protein is defective or missing it fails to silence an imprinted allele so the expression of the gene would be two times greater. Failure to repress imprinted
Table 1. Potential MeCP2 target genes and their function

\begin{tabular}{|c|c|c|}
\hline $\begin{array}{l}\text { Potential MeCP2 } \\
\text { target genes }\end{array}$ & Function & Ref. \\
\hline $\begin{array}{l}\text { LINE-1 } \\
\text { (Long interspersed } \\
\text { nuclear elements) }\end{array}$ & retrotransposons & 46 \\
\hline Leukosialin & $\begin{array}{l}\text { major sialoglycoprotein on the } \\
\text { surfaces of hematopoietic cells; } \\
\text { role in signal transduction and } \\
\text { cell adhesion }\end{array}$ & 47 \\
\hline $\begin{array}{l}B D N F \\
\text { (brain-derived } \\
\text { neurotrophic factor) }\end{array}$ & $\begin{array}{l}\text { neural plasticity, learning and } \\
\text { memory }\end{array}$ & 48,49 \\
\hline $\begin{array}{l}\text { DLX5 } \\
\text { (distal-less } \\
\text { homeobox 5) }\end{array}$ & $\begin{array}{l}\text { production of enzymes that } \\
\text { synthesize } \gamma \text {-aminobutyric acid } \\
\text { (GABA) }\end{array}$ & 51 \\
\hline $\begin{array}{l}\text { Crh } \\
\text { (corticotropin- } \\
\text { releasing hormone) }\end{array}$ & $\begin{array}{l}\text { corticotropin-releasing hormone } \\
\text { production }\end{array}$ & 53 \\
\hline $\begin{array}{l}\text { FXYD1 } \\
\text { (FXYD domain- } \\
\text { containing transport } \\
\text { regulator } 1 \text { ) }\end{array}$ & $\begin{array}{l}\text { Phospholemman production } \\
\text { (single spanning membrane } \\
\text { protein that controls cell } \\
\text { excitability by modulating } \\
\mathrm{Na}^{+} / \mathrm{K}^{+} \text {-ATPase activity) }\end{array}$ & 54 \\
\hline
\end{tabular}

alleles has been implicated in several neurological disorders. Horike et al. [55] reported that the maternally expressed DLX5 showed a loss of imprinting in lymphoblastoid cells from RTT patients, possibly resulting in changed GABAergic neuron activity in individuals with the RTT. They also found a completely new mechanism of gene regulation mediated by $\mathrm{MeCP} 2$ through the formation of a 
silent chromatin loop. In wild-type mice, Mecp2 forms a loop of silent, methylated chromatin near the location of the DLX5 and DLX6 genes; this loop regulates the expression of the DLX5 gene. However, in knockout mice that cannot produce Mecp2, this region of the chromatin is acetylated and active so different looping brings together widely separated chromatin segments. Consequently, the $D L X 5$ gene expression is highly increased. However, recently Schüle et al. [56] reported that DLX5 and DLX6 are not imprinted and are not influenced by MeCP 2 deficiency. Their results showed that the expression of $D l x 5$ and $D l x 6$ and the imprinted gene Peg3 in the mouse forebrain was highly variable and Mecp2-null mutant or control status had no actual influence on their expression. They concluded that DLX5 and DLX6 are not imprinted in humans and probably are not $\mathrm{MeCP} 2$ target genes.

In 2006, McGill et al. [57] identified another potential $\mathrm{MeCP} 2$ target gene. They studied mice bearing a truncation mutation $\left(M e c p 2^{308 / y}\right)$ and found that the expression of the gene for the corticotropin-releasing hormone (Crh) is increased in the paraventricular nucleus of the hypothalamus, the central amygdala, and the bed nucleus of the stria terminalis. In addition, they found that while wild-type Mecp2 binds to the methyl CpG-rich Crh promoter, truncated Mecp $2^{308}$ does not.

In 2007, Deng et al. [58] identified another potential $\mathrm{MeCP} 2$ target gene, FXYD domain-containing transport regulator 1 (FXYD1). This gene codes for phospholemman (PLM, FXYD1), a small, single-spanning membrane protein that controls cell excitability by modulating $\mathrm{Na}^{+} /$ $\mathrm{K}^{+}$-ATPase activity. They showed that FXYD1 expression is increased in the frontal cortex of RTT patients and Mecp2-null mice. In addition, they showed that MeCP2 binds to sequences in the FXYD1 promoter and represses its transcription [58].

\section{Mouse Models for the RTT}

To clarify the mechanisms of this disease, several animal models have been generated. Mecp2-null mice and conditional mouse mutants with selective loss of Mecp2 in the brain develop clinical features that resemble some of the symptoms of RTT patients. Mecp2-null mice were developing normally until 5 weeks of age, when they started developing the disease which led to death between 6 and 12 weeks. In addition, the brain weight and neuronal cell size were reduced with no structural defects or signs of neurodegeneration. In one conditional mutant the Mecp2 gene was deleted early in neurons while in the other it was deleted only in postmitotic, differentiated neurons. The phenotype of the first mutant was identical to the null mutation phenotype; this shows that the phenotype is caused by Mecp2 deficiency in the central nervous system rather than in peripheral tissues. The deletion in the second mutant resulted in a similar phenotype but at a later age. These results indicate that the role of Mecp2 is critical in mature neurons. It was suggested that an appropriate genetic mouse model for the RTT may be a female mouse heterozygous for the Mecp2-null allele [59]. Shahbazian et al. [60] developed a model of the RTT in male mice by replacing the wild-type allele with one encoding a truncated protein; the mice showed many features similar to those found in RTT patients.

Collins et al. [61] developed a model that transgenically expresses MeCP2 under the endogenous human promoter; this showed that even a mild overexpression of $\mathrm{MeCP} 2$ causes a progressive neurological disorder in mice and premature death. Additionally, they crossed the Mecp2-null mice with the overexpressing transgenic mice and demonstrated that expression of a human MECP2 gene rescues the loss of the mouse Mecp2. They also showed that by removing the endogenous allele and therefore reducing the Mecp2 levels, the overexpression phenotype is rescued; this revealed that the effects in transgenic mice were a result of the overexpression of Mecp2.

Mouse models have become a very useful tool for finding new Mecp2 target genes as well as for new genes responsible for the RTT. Jordan et al. [62] performed a microarray-based global gene expression study in the cerebellum of Mecp2-mutant mice by comparing transcript levels in mutant/wild-type male sibs of two different Mecp2-deficient mouse models at 2, 4 and 8 weeks of age. They found 4 genes with increased expression in Mecp2mutant mice that could be possible new targets for Mecp2 research: Irak1 (interleukin-1 receptor-associated kinase 1), Fxyd1 (phospholemman, associated with $\mathrm{Na}^{+} / \mathrm{K}^{+}$ATPase), Reln (encoding an extracellular signaling molecule essential for neuronal lamination and synaptic plasticity), and Gtl2/Meg3 (an imprinted maternally expressed nontranslated RNA that serves as a host gene for C/D box snoRNAs and microRNAs).

\section{Conclusion}

It is now well known that most of the cases with RTT are caused by mutations in the MECP2 gene but recent findings reported that two additional genes (CDKL5 and Netrin G1) can also be involved in the pathogenesis of this 
syndrome. There is also evidence for the hypothesis that CDKL5 and MECP2 together play an important role in the RTT since it was shown that CKDL5 phosphorylates $\mathrm{MeCP}$. Additional research is required for these findings to be fully confirmed and further exploration should be directed towards the discovery of other possible $\mathrm{MeCP} 2$ target genes. Few of the potential genes have been discovered but we will certainly know more about this disorder and about the MeCP2 protein itself following additional findings of target genes.

\section{Acknowledgement}

This work was supported by grant No. 098-0982464-2394 from the Ministry of Science, Education and Sports, Republic of Croatia.

\section{References}

1 Rett A: On a unusual brain atrophy syndrome in hyperammonemia in childhood. Wien Med Wochenschr 1966;116:723-726.

$\checkmark 2$ Hagberg B, Aicardi J, Dias K, Ramos O: A progressive syndrome of autism, dementia, ataxia, and loss of purposeful hand use in girls: Rett's syndrome: report of 35 cases. Ann Neurol 1983;14:471-479.

-3 Williamson SL, Christodoulou J: Rett syndrome: new clinical and molecular insights. Eur J Hum Genet 2006;14:896-903.

-4 Weaving LS, Ellaway CJ, Gecz J, Christodoulou J: Rett syndrome: clinical review and genetic update. J Med Genet 2005;42:1-7.

-5 Sekul EA, Moak JP, Schultz RJ, Glaze DG, Dunn JK, Percy AK: Electrocardiographic findings in Rett syndrome: an explanation for sudden death? J Pediatr 1994;125:80-82.

-6 Amir RE, Van den Veyver IB, Wan M, Tran CQ, Francke U, Zoghbi HY: Rett syndrome is caused by mutations in X-linked MECP2, encoding methyl-CpG-binding protein 2 . Nat Genet 1999;23:185-188.

-7 D'Esposito M, Quaderi NA, Ciccodicola A, Bruni P, Esposito T, D’Urso M, Brown SD: Isolation, physical mapping, and northern analysis of the X-linked human gene encoding methyl CpG-binding protein, MECP2. Mamm Genome 1996;7:533-535.

-8 Sirianni N, Naidu S, Pereira J, Pilloto RF, Hoffman EP: Rett syndrome: confirmation of X-linked dominant inheritance, and localization of the gene to Xq28. Am J Hum Genet 1998;63:1552-1558.

-9 Mnatzakanian GN, Lohi H, Munteanu I, Alfred SE, Yamada T, MacLeod PJ, Jones JR, Scherer SW, Schanen NC, Friez MJ, Vincent JB, Minassian BA: A previously unidentified MECP2 open reading frame defines a new protein isoform relevant to Rett syndrome. Nat Genet 2004;36:339-341.

-10 Coy JF, Sedlacek Z, Bächner D, Delius H, Poustka A: A complex pattern of evolutionary conservation and alternative polyadenylation within the long $3^{\prime}$-untranslated region of the methyl-CpG-binding protein 2 gene $(\mathrm{MeCP} 2)$ suggests a regulatory role in gene expression. Hum Mol Genet 1999;8: 1253-1262.

- 11 Yu F, Thiesen J, Stratling WH: Histone deacetylase-independent transcriptional re- pression by methyl-CpG-binding protein 2 . Nucleic Acids Res 2000;28:2201-2206.

12 Nan X, Campoy FJ, Bird A: MeCP2 is a transcriptional repressor with abundant binding sites in genomic chromatin. Cell 1997;88: 471-481.

13 Colantuoni C, Jeon OH, Hyder K, Chenchik A, Khimani AH, Narayanan V, Hoffman EP, Kaufmann WE, Naidu S, Pevsner J: Gene expression profiling in postmortem Rett syndrome brain: differential gene expression and patient classification. Neurobiol Dis 2001;8:847-865

14 Tudor M, Akbarian S, Chen RZ, Jaenisch R: Transcriptional profiling of a mouse model for Rett syndrome reveals subtle transcriptional changes in the brain. Proc Natl Acad Sci USA 2002;99:15536-15541.

15 Nagai K, Miyake K, Kubota T: A transcriptional repressor $\mathrm{MeCP} 2$ causing Rett syndrome is expressed in embryonic non-neuronal cells and controls their growth. Brain Res Dev Brain Res 2005;157:103-106.

16 Smrt RD, Eaves-Egenes J, Barkho BZ, Barkho BZ, Santistevan NJ, Zhao C, Aimone JB, Gage FH, Zhao X: Mecp2 deficiency leads to delayed maturation and altered gene expression in hippocampal neurons. Neurobiol Dis 2007;27:77-89.

17 Nikitina T, Ghosh RP, Horowitz-Scherer RA, Hansen JC, Grigoryev SA, Woodcock CL: MeCP2-chromatin interactions include the formation of chromatosome-like structures and are altered in mutations causing Rett syndrome. J Biol Chem 2007;282:2823728245.

18 Nan X, Hou J, Maclean A, Nasir J, Lafuente MJ, Shu X, Kriaucionis S, Bird A: Interaction between chromatin proteins MECP2 and ATRX is disrupted by mutations that cause inherited mental retardation. Proc Natl Acad Sci USA 2007;104:2709-2714.

19 Shahbazian MD, Zoghbi HY: Molecular genetics of Rett syndrome and clinical spectrum of MECP2 mutations. Curr Opin Neurol 2001;14:171-176.

20 Djarmati A., Dobricic V, Kecmanović M, Marsh P, Jancić-Stefanović J, Klein C, Djurić M, Romac S: MECP2 mutations in Serbian Rett syndrome patients. Acta Neurol Scand 2007;116:413-419.
21 Matijevic T, Knezevic J, Barišić I, Rešić B, Čulić V, Pavelić J: The MECP2 gene mutation screening in Rett syndrome patients from Croatia. Ann NY Acad Sci 2006;1091:225232.

22 Zahorakova D, Rosipal R, Hadac J, Zumrova A, Bzduch V, Misovicova N, Baxova A, Zeman J, Martasek P: Mutation analysis of the MECP2 gene in patients of Slavic origin with Rett syndrome: novel mutations and polymorphisms. J Hum Genet 2007;52:342348 .

$\checkmark 23$ Vacca M, Filippini F, Budillon A, Rossi V, Della Ragione F, De Bonis ML, Mercadante G, Manzati E, Gualandi F, Bigoni S, Trabanelli C, Pini G, Calzolari E, Ferlini A, Meloni I, Hayek G, Zappella M, Renieri A, D'Urso M, D'Esposito M, Macdonald F, Kerr A, Dhanjal S, Hulten M: MECP2 gene mutation analysis in the British and Italian Rett Syndrome patients: hot spot map of the most recurrent mutations and bioinformatic analysis of a new MECP2 conserved region. Brain Dev 2001;23(suppl 1):S246-S250.

24 Yamada Y, Miura K, Kumagai T, Hayakawa C, Miyazaki S, Matsumoto A, Kurosawa K, Nomura N, Taniguchi H, Sonta SI, Yamanaka T, Wakamatsu N: Molecular analysis of Japanese patients with Rett syndrome: identification of five novel mutations and genotype-phenotype correlation. Hum Mutat 2001;18:253.

25 Yaron Y, Ben Zeev B, Shomrat R, Bercovich D, Naiman T, Orr-Urtreger A: MECP2 mutations in Israel: implications for molecular analysis, genetic counseling, and prenatal diagnosis in Rett syndrome. Hum Mutat 2002;20:323-324.

26 Pan H, Wang YP, Bao XH, Meng HD, Zhang Y, Wu XR, Shen Y: MECP2 gene mutation analysis in Chinese patients with Rett syndrome. Eur J Hum Genet 2002;10:484486.

27 Fukuda T, Yamashita Y, Nagamitsu S, Miyamoto K, Jin JJ, Ohmori I, Ohtsuka Y, Kuwajima K, Endo S, Iwai T, Yamagata H, Tabara Y, Miki T, Matsuishi T, Kondo I: Methyl-CpG binding protein 2 gene (MECP2) variations in Japanese patients with Rett syndrome: pathological mutations and polymorphisms. Brain Dev 2005;27:211-217. 
28 Philippe C, Villard L, De Roux N, Raynaud M, Bonnefond JP, Pasquier L, Lesca G, Mancini J, Jonveaux P, Moncla A, Chelly J, Bienvenu T: Spectrum and distribution of MECP2 mutations in 424 Rett syndrome patients: a molecular update. Eur J Med Genet 2006;49:9-18.

-29 Weaving LS, Christodoulou J, Williamson SL, Friend KL, McKenzie OL, Archer H, Evans J, Clarke A, Pelka GJ, Tam PP, Watson C, Lahooti $\mathrm{H}$, Ellaway CJ, Bennetts B, Leonard H, Gécz J: Mutations of CDKL5 cause a severe neurodevelopmental disorder with infantile spasms and mental retardation. Am J Hum Genet 2004;75:1079-1093.

- 30 Tao J, Van Esch H, Hagedorn-Greiwe M, Hoffmann K, Moser B, Raynaud M, Sperner J, Fryns JP, Schwinger E, Gécz J, Ropers HH, Kalscheuer VM: Mutations in the X-linked cyclin-dependent kinase-like 5 (CDKL5/ STK9) gene are associated with severe neurodevelopmental retardation. Am J Hum Genet 2004;75:1149-1154.

- 31 Mari F, Azimonti S, Bertani I, Bolognese F, Colombo E, Caselli R, Scala E, Longo I, Grosso S, Pescucci C, Ariani F, Hayek G, Balestri P, Bergo A, Badaracco G, Zappella M, Broccoli V, Renieri A, Kilstrup-Nielsen C, Landsberger N: CDKL5 belongs to the same molecular pathway of $\mathrm{MeCP} 2$ and it is responsible for the early-onset seizure variant of Rett syndrome. Hum Mol Genet 2005; 14:1935-1946.

- 32 Bertani I, Rusconi L, Bolognese F, Forlani G, Conca B, De Monte L, Badaracco G, Landsberger N, Kilstrup-Nielsen C: Functional consequences of mutations in CDKL5, an Xlinked gene involved in infantile spasms and mental retardation. J Biol Chem 2006;281: 32048-32056.

- 33 Borg I, Freude K, Kübart S, Hoffmann K, Menzel C, Laccone F, Firth H, FergusonSmith MA, Tommerup N, Ropers HH, Sargan D, Kalscheuer VM: Disruption of Netrin G1 by a balanced chromosome translocation in a girl with Rett syndrome. Eur J Hum Genet 2005; 13:921-927.

- 34 Archer HL, Evans JC, Millar DS, Thompson PW, Kerr AM, Leonard H, Christodoulou J, Ravine D, Lazarou L, Grove L, Verity C, Whatley SD, Pilz DT, Sampson JR, Clarke AJ: NTNG1 mutations are a rare cause of Rett syndrome. Am J Med Genet A 2006;140: 691-694.

- 35 Bienvenu T, Carrie A, de Roux N, Vinet MC, Jonveaux P, Couvert P, Villard L, Arzimanoglou A, Beldjord C, Fontes M, Tardieu M, Chelly J: MECP2 mutations account for most cases of typical forms of Rett syndrome. Hum Mol Genet 2000;9:1377-1384.

- 36 Amir RE, Van den Veyver IB, Schultz R, Malicki DM, Tran CQ, Dahle EJ, Philippi A, Timar L, Percy AK, Motil KJ, Lichtarge O, Smith EO, Glaze DG, Zoghbi HY: Influence of mutation type and $\mathrm{X}$ chromosome inactivation on Rett syndrome phenotypes. Ann Neurol 2000;47:670-679.
7 Renieri A, Meloni I, Longo I, Ariani F, Mari F, Pescucci C, Cambi F: Rett syndrome: the complex nature of a monogenic disease. J Mol Med 2003;81:346-354.

- 38 Cheadle JP, Gill H, Fleming N, Maynard J, Kerr A, Leonard H, Krawczak M, Cooper DN, Lynch S, Thomas N, Hughes H, Hulten M, Ravine D, Sampson JR, Clarke A: Longread sequence analysis of the MECP2 gene in Rett syndrome patients: correlation of disease severity with mutation type and location. Hum Mol Genet 2000;9:1119-1129.

39 Monros E, Armstrong J, Aibar E, Poo P, Canós I, Pineda M: Rett syndrome in Spain: mutation analysis and clinical correlations. Brain Dev 2001;23(suppl 1):S251-S253.

40 Huppke P, Held M, Laccone F, Hanefeld F: The spectrum of phenotypes in females with Rett Syndrome. Brain Dev 2003;25:346351.

41 Huppke P, Held M, Hanefeld F, Engel W, Laccone F: Influence of mutation type and location on phenotype in 123 patients with Rett syndrome. Neuropediatrics 2002;33:63-68.

42 Scala E, Longo I, Ottimo F, Speciale C, Sampieri K, Katzaki E, Artuso R, Mencarelli MA, D’Ambrogio T, Vonella G, Zappella M, Hayek G, Battaglia A, Mari F, Renieri A, Ariani F: MECP2 deletions and genotype-phenotype correlation in Rett syndrome. Am J Med Genet A 2007;143:2775-2784.

43 Zoghbi HY, Percy AK, Schultz RJ, Fill C: Patterns of $\mathrm{X}$ chromosome inactivation in the Rett syndrome. Brain Dev 1990;12:131-135.

44 Archer H, Evans J, Leonard H, Colvin L, Ravine $\mathrm{D}$, Christodoulou J, Williamson $\mathrm{S}$, Charman T, Bailey ME, Sampson J, de Klerk $\mathrm{N}$, Clarke A: Correlation between clinical severity in patients with Rett syndrome with a p.R168X or p.T158M MECP2 mutation, and the direction and degree of skewing of $\mathrm{X}$ chromosome inactivation. J Med Genet 2007;44:148-152.

45 Villard L: MECP2 mutations in males. J Med Genet 2007;44:417-423.

46 Clayton-Smith J, Watson P, Ramsden S, Black GC: Somatic mutation in MECP2 as a non-fatal neurodevelopmental disorder in males. Lancet 2000;356:830-832.

47 Schwartzman JS, De Souza AM, Faiwichow G, Hercowitz LH: Rett phenotype in patient with XXY karyotype: case report. Arq Neuropsiquiatr 1998;56:824-828.

48 Maiwald R, Bonte A, Jung H, Bitter P, Storm Z, Laccone F, Herkenrath P: De novo MECP2 mutation in a 46,XX male patient with Rett syndrome. Neurogenetics 2002;4:107-108.

-49 Orrico A, Lam C, Galli L, Dotti MT, Hayek G, Tong SF, Poon PM, Zappella M, Federico A, Sorrentino V: MECP2 mutation in male patients with non-specific X-linked mental retardation. FEBS Lett 2000;481:285-288.
50 Yu F, Zingler N, Schumann G, Strätling WH: Methyl-CpG-binding protein 2 represses LINE-1 expression and retrotransposition but not Alu transcription. Nucleic Acids Res 2001;29:4493-4501.

-51 Kudo S: Methyl-CpG-binding protein $\mathrm{MeCP} 2$ represses Sp1-activated transcription of the human leukosialin gene when the promoter is methylated. Mol Cell Biol 1998; 18:5492-5499.

-52 Chen WG, Chang Q, Lin Y, Meissner A, West AE, Griffith EC, Jaenisch R, Greenberg ME: Derepression of BDNF transcription involves calcium-dependent phosphorylation of MeCP2. Science 2003;302:885-889.

-53 Martinowich K, Hattori D, Wu H, Fouse S, He F, Hu Y, Fan G, Sun YE: DNA methylation-related chromatin remodeling in activity-dependent BDNF gene regulation. Science 2003;302:890-893.

54 Chang Q, Khare G, Dani V, Nelson S, Jaenisch R: The disease progression of Mecp2 mutant mice is affected by the level of BDNF expression. Neuron 2006;49:341-348.

55 Horike S, Cai S, Miyano M, Cheng JF, Kohwi-Shigematsu T: Loss of silent-chromatin looping and impaired imprinting of DLX5 in Rett syndrome. Nat Genet 2005;37:31-40.

56 Schüle B, Li HH, Fisch-Kohl C, Purmann C, Francke U: DLX5 and DLX6 expression is biallelic and not modulated by $\mathrm{MeCP} 2$ deficiency. Am J Hum Genet 2007;81:492-506.

57 McGill BE, Bundle SF, Yaylaoglu MB, Carson JP, Thaller C, Zoghbi HY: Enhanced anxiety and stress-induced corticosterone release are associated with increased Crh expression in a mouse model of Rett syndrome. Proc Natl Acad Sci USA 2006;103:1826718272.

-58 Deng V, Matagne V, Banine F, Frerking M, Ohliger P, Budden S, Pevsner J, Dissen GA, Sherman LS, Ojeda SR: FXYD1 is an MeCP2 target gene overexpressed in the brains of Rett syndrome patients and Mecp2-null mice. Hum Mol Genet 2007;16:640-650.

-59 Chen RZ, Akbarian S, Tudor M, Jaenisch R: Deficiency of methyl-CpG binding protein-2 in CNS neurons results in a Rett-like phenotype in mice. Nat Genet 2001;27:327-331.

60 Shahbazian M, Young J, Yuva-Paylor L, Spencer C, Antalffy B, Noebels J, Armstrong D, Paylor R, Zoghbi H: Mice with truncated $\mathrm{MeCP} 2$ recapitulate many Rett syndrome features and display hyperacetylation of histone H3. Neuron 2002;35:243-254.

61 Collins AL, Levenson JM, Vilaythong AP, Vilaythong AP, Richman R, Armstrong DL, Noebels JL, David Sweatt J, Zoghbi HY: Mild overexpression of $\mathrm{MeCP} 2$ causes a progressive neurological disorder in mice. Hum Mol Genet 2004;13:2679-2689.

-62 Jordan C, Li HH, Kwan HC, Francke U: Cerebellar gene expression profiles of mouse models for Rett syndrome reveal novel MeCP2 targets. BMC Med Genet 2007;8:36. 